\title{
Schwannoma of the Tongue: A report of Two Cases and Review
}

\author{
Evren Erkul (*), Hakan Cıncık (*), Abtullah Haholu (**), Engin Çekin (*), Atila Güngör (*)
}

\begin{abstract}
SUMMARY
The aim of this study is to present clinicopathologic characteristics of two cases with schwannoma of the tongue and to review the literature. Both cases with mass in tongue underwent surgery by intraoral approach and histopathologic diagnosis of both was schwannoma. English medical literature for articles reporting tongue schwannoma from year 1996 to 2010 was searched in Pubmed. 67 cases were found in English, 48 cases had full text document and 42 of them were providing specified criteria. The average age was 30.92 . There was no significant difference regarding sex (24 male, 18 female). Masses were located at the tip of tongue in 9 cases, at the base in 10 cases, at the lateral side in 16 cases, at the ventral surface in 6 cases and at the sublingual surface in 1 case. Painless swelling and tenderness were the most significant symptoms. Intraoral approach was used for 38 cases, suprahyoid pharyngotomy approach was used for 2 cases, and other two were excised by submandibular approach. Total surgical excision is the treatment of choice and intraoral resection was the common approach for majority of tongue schwannomas.
\end{abstract}

Key words: Schwannoma, tongue, lingual, neurilemmoma

ÖZET

Horner sendromu: tüp torakostominin oldukça nadir görülen bir komplikasyonu

Bu çalışmanın amacı iki dil schwannomalı olguyu klinikopatolojik özellikleri ile sunmak ve ayrıca literatür derlemesini yapmaktır. Her iki olguda intraoral yaklaşımla ameliyat edilmiş ve histopatolojik tanıları schwannomadır. Pubmed aracilığıla İngilizce tıbbi literatürde rapor edilmiş olan dil schwanomlu olgular 1996 ile 2010 yılları arasında taranmıştır. İngilizce olan 67 olguda, 48'nin tam metnine ulaşılmış ve bunların 42'si tüm kriterleri sağlamıştır. Ortalama yaş 30.92 dir. Cinsiyet dağılımında belirgin fark yoktur (24 erkek, 18 bayan). Kitlelerin 9'u tipte, 10'u tabanda, 16's lateralde, 6 'sı ventral yüzde ve 1'i sublingual yüzde yerleșimlidir. En belirgin semptomlar ağrısız kitle ve gerginliktir. 38 olgunun tedavisinde intraoral yaklaşım kullanılmışırı. İki olgu suprahyoid farengotomi yaklaşımı ile ve diğer ikisi submandibular yaklaşımla eksize edilmiştir. Tedavi seçeneği tam cerrahi eksizyondur ve dil schwannomlarının büyük çoğunluğunda intraoral rezeksiyon yaygın yaklaşım olarak tercih edilmiştir.

Anahtar kelimeler: Schwannoma, dil, lingual, nörilemmoma

\footnotetext{
* GATA Haydarpaşa Eğitim Hastanesi KBB Servisi

${ }^{* *}$ GATA Haydarpaşa Eğitim Hastanesi Patoloji Servisi

This sudy was presented as a poster presentation at 32. National ENT and Head and Neck Congress in Antalya at 27-31th of October, 2010.

Reprint request: Dr. Evren ERKUL, GATA Haydarpaşa Eğitim Hastanesi, KBB Klinigi 34668 Kadıköy / İstanbul

E-mail: evrenerkul@yahoo.com
}

Date submitted: August 05, 2011 Date accepted: March 15, 2012 Online publication date: June 27, 2013

\section{Introduction}

Neurogenic tumors include malignant and benign variants; benign group constitute neurofibroma, schwannoma, neuroma and perineuroma; malignant group constitutes malign peripheral nerve sheath tumors (neurogenic sarcoma, neurofibrosarcoma, malignant schwannoma) $(1,2)$. Schwannoma was first defined in 1906 by Verocay J. (3). The tumor originated from autonomic nervous system, cranial nerves (except the optic and olfactory nerves) and peripheral nerves $(2,3)$. These tumors can arise from any nerve covered with Schwann cell sheath (2).

Schwannoma occurs $11-45 \%$ in the head and neck region $(2,3)$. The lateral sides of the neck and paranasal sinuses are more prevalent (2). Extracranial schwannomas are rarely presented at the tongue and the floor of the mouth. Approximately $1-12 \%$ of these tumors have been found in intraoral location and tongue is the most common site (3). The tumor is frequently smooth-surfaced, slow growing, solitary and asymptomatic $(2,3,4)$. It occasionally causes pain or discomfort. Schwannoma shows no recurrence if completely excised $(5,6,7)$.

We present two cases with tongue schwannoma and also review English medical literature about it.

\section{Case Reports}

First case was a 21 year-old man admitted to our clinic with history of slowly enlarging tongue mass in a period of one year. Physical examination showed a non-tender, elastic, oval, 20x30 mm sized mass with smooth mucosal surface at the left side of the tongue (Figure 1). In physical examination, no other finding was found. The patient described discomfort in chewing, but there were no changes in swallowing and taste functions. His medical history was unremarkable. The case was operated for diagnosis 
and treatment under local anesthesia. A vertical incision was made and encapsulated mass was excised by submucosal blunt dissection. Tracheostomy was not needed. During postoperative period, edema was seen at left side of tongue but it was regressed totally in a week. Macroscopic examination of the mass revealed well capsulated, yellow-grey colour mass. Histopathological diagnosis was schwannoma. There was no recurrence during 17 months of follow up.

The second case was a 21-year-old man with complaint of a mass on the tip of his tongue for seven months. He had no pain. Physical examination showed a non-tender, elastic, oval, 15x20 mm sized mass with smooth mucosal surface at the tip of tongue. Other findings in his physical examination was unremarkable. The mass was excised by intraoral approach. Histopathological evaluation showed an intact superficial epithelium, myxomatous stroma and spindle Schwann cells inside hypercellular (Antoni A) and hypocellular (Antoni B) areas (Figure 2). S-100 protein was positive but there was no mitosis or atypia (Figure 3). There was no recurrence during 23 months follow up.

\section{Review Results}

The English medical literature was searched in Pubmed from 1996 to 2010 using key words as schwannoma, neurilemmoma, tongue schwannoma and lingual schwannoma. The cases were accepted for the review if they provided enough data about following criteria; surgical approach, sex, age, size, location of the masses. The cases were analyzed according to the criteria and also assessed the radiological and diagnostic approaches and modalities. All cases had been confirmed as schwannoma histopathologically.

We found 87 cases with tongue schwannoma in Pubmed, and 67 cases were reported in English. 48 cases had full-text documents and they were reviewed but 6 articles were not providing all criteria. The remaining 42 cases, which were accepted for review, are shown in Table I.

The masses were seen at all age ranges, nevertheless it was mostly seen in the second and fourth decades of life, and the average age was 30.92 (range 7-77 years). The age distribution of the cases is shown in Table II. Sex predilection was nearly equal ( 24 males and 18 females).

The most common symptoms of the patients with tongue schwannomas were painless swelling,

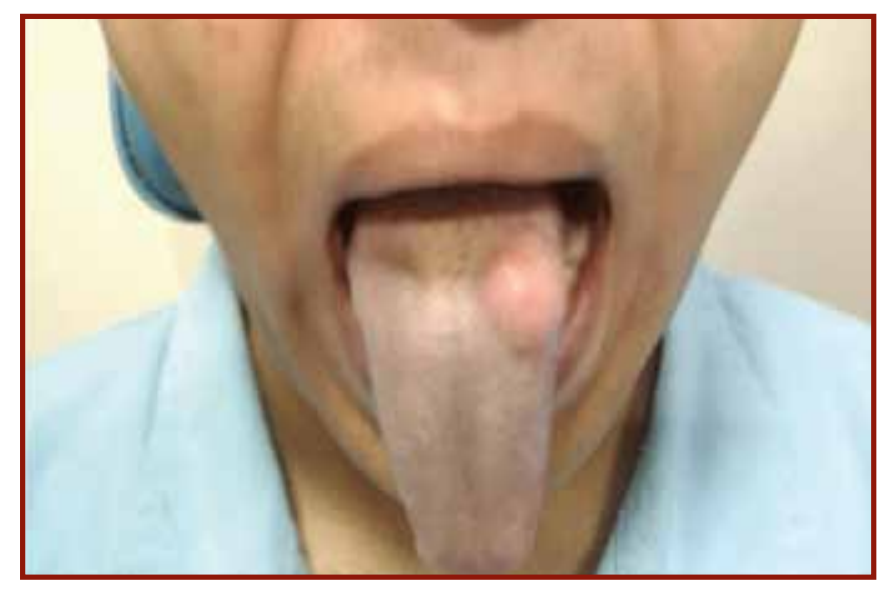

Figure 1. Schwannoma at the left side of the tongue

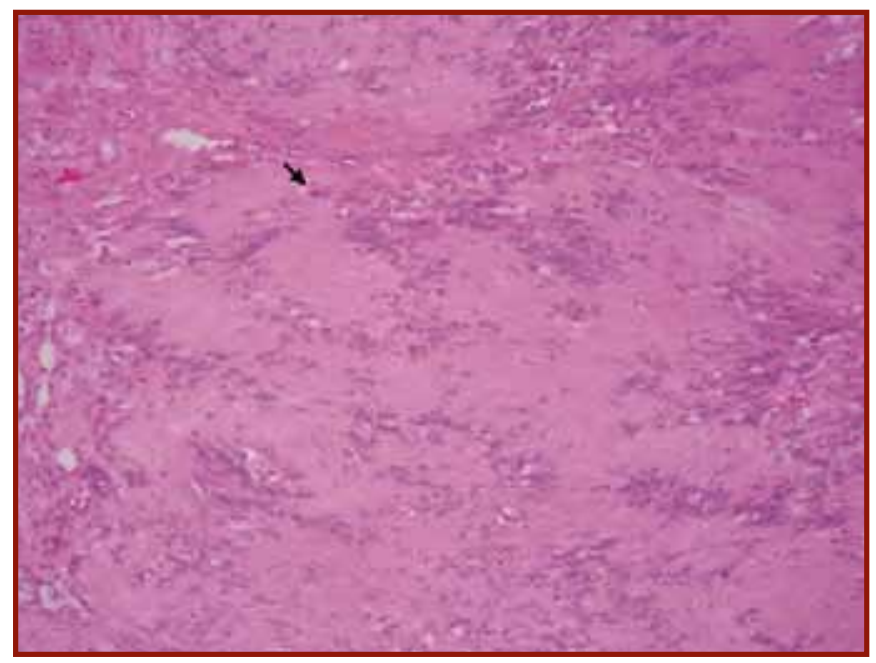

Figure 2. Antoni A (cellular region) areas forming Verocay bodies (black arrow) (Hematoxylin-eosin stain, original magnification X 200).

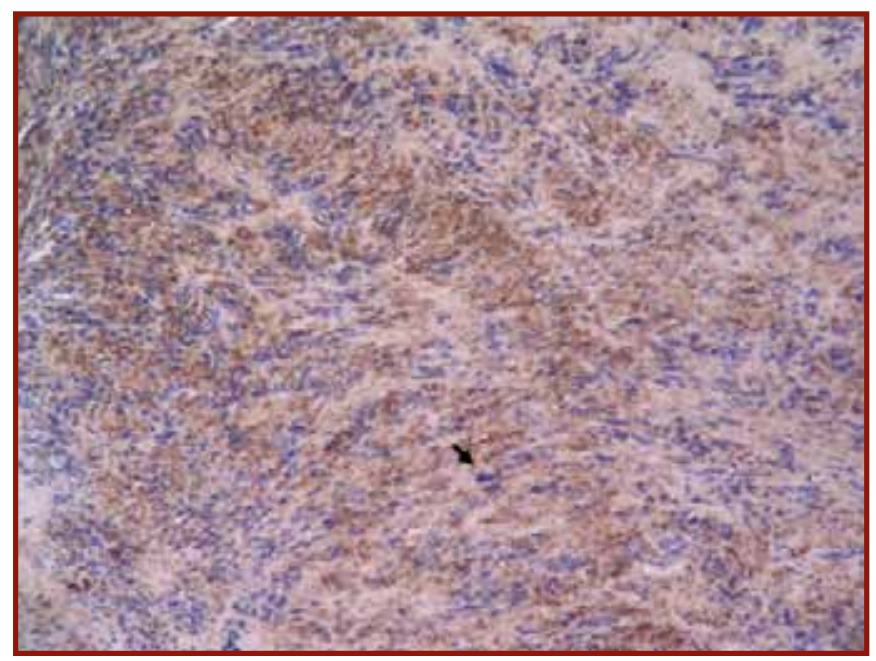

Figure 3. S-100 protein was positive (original magnification X 100)

tenderness, pain, and otalgia sequentially. Most of the patients (\%71) had a painless swelling; however the patients with tongue base schwannoma (approximately $30 \mathrm{~mm}$ ) had rare symptoms such as snoring, dysphagia and change in the voice quality. 
Table I. Cases and clinical features

\begin{tabular}{|c|c|c|c|c|c|c|c|c|}
\hline No. & Authors & Year & Case & Age & Sex & Location & $\begin{array}{l}\text { Size (greatest } \\
\text { dimension } \mathrm{mm} \text { ) }\end{array}$ & $\begin{array}{l}\text { Surgical } \\
\text { Approach }\end{array}$ \\
\hline 1 & Karaca (34) & 2010 & 1 & 13 & $M$ & Tip & 20 & Intraoral excision \\
\hline 2 & Luksic (35) & 2010 & 1 & 20 & $M$ & Left side & 15 & Intraoral excision \\
\hline 3 & Jeffcoat (36) & 2010 & 1 & 68 & $M$ & Right side & 20 & Intraoral excision \\
\hline 4 & Santos (37) & 2010 & 1 & 18 & $M$ & Base & 17 & Intraoral excision \\
\hline 5 & Naidou (38) & 2010 & 1 & 12 & $M$ & Ventral & 20 & Intraoral excision \\
\hline 6 & Gupta (39) & 2009 & 1 & 18 & $M$ & Tip & 10 & Intraoral excision \\
\hline \multirow[t]{2}{*}{7} & Cohen (40) & 2009 & 2 & 19 & $\mathrm{~F}$ & Right side & 18 & Intraoral excision \\
\hline & & & & 77 & $M$ & Right side & 7 & Intraoral excision \\
\hline 8 & Sawhney (41) & 2008 & 1 & 37 & $\mathrm{~F}$ & Base & 46 & Submandibuler approach \\
\hline 9 & Pereira (19) & 2008 & 1 & 12 & $M$ & Ventral & 15 & Intraoral excision \\
\hline 10 & Patnayak (20) & 2007 & 1 & 45 & $\mathrm{~F}$ & Left side & 30 & Intraoral excision \\
\hline 11 & Mehrzad (17) & 2006 & 1 & 49 & $M$ & Base & 22 & Intraoral excision with CO2 Laser \\
\hline \multirow[t]{10}{*}{12} & Hsu (16) & 2006 & 10 & 39 & $\mathrm{~F}$ & Left side & 10 & Intraoral excision \\
\hline & & & & 39 & $\mathrm{~F}$ & Left side & 40 & Suprahyoid Pharyngotomy \\
\hline & & & & 9 & M & Left side & 12 & Intraoral excision \\
\hline & & & & 32 & $\mathrm{~F}$ & Base & 18 & Intraoral excision \\
\hline & & & & 25 & M & Right side & 9 & Intraoral excision \\
\hline & & & & 15 & $\mathrm{~F}$ & Left side & 12 & Intraoral excision \\
\hline & & & & 38 & M & Tip & 30 & Intraoral excision \\
\hline & & & & 12 & $\mathrm{~F}$ & Left side & 16 & Intraoral excision \\
\hline & & & & 45 & M & Tip & 5 & Intraoral excision \\
\hline & & & & 20 & M & Base & 50 & Intraoral excision \\
\hline 13 & Ying (13) & 2006 & 1 & 26 & $\mathrm{~F}$ & Base & 40 & Suprahyoid Pharyngotomy \\
\hline 14 & Enoz (21) & 2006 & 1 & 7 & M & Tip & 25 & Intraoral excision \\
\hline 15 & Sardinha (22) & 2005 & 1 & 13 & M & Ventral & 14 & Intraoral excision \\
\hline 16 & Hwang (10) & 2005 & 1 & 23 & M & Tip & 20 & Intraoral excision \\
\hline 17 & Cinar (7) & 2005 & 1 & 7 & M & Tip & 10 & Intraoral excision \\
\hline 18 & Nakasato (23) & 2005 & 1 & 9 & $\mathrm{~F}$ & Base & 30 & Intraoral excision \\
\hline 19 & Jomet (24) & 2005 & 1 & 39 & M & Right Side & 8 & Intraoral excision \\
\hline 20 & Vafiadis (25) & 2005 & 1 & 18 & $M$ & Tip & 35 & Intraoral excision \\
\hline 21 & Bassichis (26) & 2004 & 1 & 9 & $M$ & Base pediculated & 23 & Intraoral excision \\
\hline 22 & Tamaki (27) & 2004 & 1 & 74 & $M$ & Left side & 30 & Intraoral excision \\
\hline 23 & Kumar (28) & 2004 & 1 & 18 & $\mathrm{~F}$ & Right side & 40 & Intraoral excision \\
\hline 24 & Arda (29) & 2003 & 1 & 34 & $\mathrm{~F}$ & Sublingual & 30 & Intraoral excision \\
\hline 25 & Mevio (12) & 2002 & 1 & 35 & $\mathrm{~F}$ & Ventral Pediculated & 20 & Intraoral excision \\
\hline 26 & Go (30) & 2002 & 1 & 39 & $M$ & Left side & 8 & Intraoral excision \\
\hline 27 & Pfeifle (13) & 2001 & 1 & 30 & $\mathrm{~F}$ & Tip & 10 & Intraoral excision \\
\hline 28 & De Bree (14) & 2000 & 1 & 18 & M & Ventral & 20 & Intraoral excision \\
\hline \multirow[t]{2}{*}{29} & Spandow (31) & 1999 & 2 & 24 & $\mathrm{~F}$ & Base & 50 & Submandibular approach \\
\hline & & & & 37 & M & Base & 79 & Intraoral excision \\
\hline 30 & Nelson (32) & 1998 & 1 & 37 & $M$ & Right side & 30 & Intraoral excision \\
\hline \multirow[t]{2}{*}{31} & Nakayama (33) & 1996 & 1 & 40 & $\mathrm{~F}$ & Ventral & 40 & Intraoral excision \\
\hline & 31 Articles & & 42 & $\begin{array}{l}\text { Mean Age: } \\
30.92\end{array}$ & $\begin{array}{l}\text { Female:18 } \\
\text { Male:24 }\end{array}$ & $\begin{array}{l}\text { Base.10 } \\
\text { Tip:9 } \\
\text { Side:16 } \\
\text { Ventral:6 } \\
\text { Sublingual:1 }\end{array}$ & $\begin{array}{l}\text { Average: } \\
23.66 \mathrm{~mm}\end{array}$ & $\begin{array}{l}\text { Intraoral:38 } \\
\text { Submandibular:2 } \\
\text { Suprahyoid pharyngotomy:2 }\end{array}$ \\
\hline
\end{tabular}




\begin{tabular}{lc} 
Table II. Age distribution of cases \\
\hline Age (Decades) & Number of cases \\
\hline $0-10$ & 5 \\
$10-20$ & 12 \\
$20-30$ & 6 \\
$30-40$ & 13 \\
$40-50$ & 3 \\
$50-60$ & - \\
60 and over & 3 \\
\hline
\end{tabular}

A patient had a huge mass $(80 \mathrm{~mm})$ at the base of the tongue, and that patients' complaint was weight loss because of swallowing difficulty in a long period.

Schwannomas located at the tip of the tongue in 9 cases as in our one case, located at base in 10 cases, at left or right side in 16 cases as in our one case, at ventral surface in 6 cases and sublingual surface of the tongue in 1 case. Only two masses had pedicles. Average sizes of the masses were 23.66 $\mathrm{mm}$ in diameter. The largest size was $79 \mathrm{~mm}$ and the smallest was $5 \mathrm{~mm}$.

In our review 10 cases were detected using MRI (Magnetic resonance imaging) study, 13 cases had CT (Computed tomography) imaging, and only three cases had needed CT and MRI together for diagnosis. Nearly half of the surgeons (20 cases) firstly preferred excisional biopsy for diagnosis instead of using imaging modalities, especially in cases with schwannoma located at ventral tip and side. Fine needle biopsies were made in seven cases for diagnosis before surgery and 4 of them were located at base, and 3 of them were at ventral side.

Masses, which were located at base and sublingual portion, were operated under general anesthesia; also two masses located laterally were operated under general anesthesia, too. Four cases were operated by suprahyoid pharyngotomy and submandibular approaches. All other cases were operated under local anesthesia by an intraoral approach (90.9\%). One patient had an intraoral laser excision for the disease. In order to prevent respiratory distress after surgery for suprahyoid and submandibular approach, tracheotomy was performed before surgeries. No serious complications were seen after surgery.

The post-operative period of cases was uneventful and no recurrence was observed. We couldn't find any information about follow-up of 3 patients. The longest follow up time was 16 years.

\section{Discussion}

Schwannomas are solid and slow-growing tumors originating from Schwann cells of the nerve sheath. Approximately $25-45 \%$ of all schwannomas occur in the head and neck region $(2,3)$. Das Gupta et al (8) reported 136 cases of schwannoma in the head and neck which consisted of 60 cases in the neck, 10 cases in the parotid gland, 9 cases in the cheek, 8 cases in the tongue, and 8 cases in the pharynx. The parapharyngeal space is the most common site in the head and neck region $(2,3) .1 \%$ of the head and neck schwannomas occur at the tongue $(1,8)$.

The possible etiologies of the tongue schwannoma are spontaneous growth, external injury, chronic irritation, or exposure to radiation; but the certain cause of the tongue schwannoma is unknown. Lee et. al reported that schwannoma of the tongue is caused by tongue bite (9). In our review one case had a tongue bite history (10). Shore-Freedman et. al (11) found 29 schwannomas in a long-term followup of more than 2000 patients who had undergone irradiation to neck. Schwannomas can arise from cranial nerves such as vagus nerve, spinal roots and peripheral nerves $(8,12)$. In review cases, the nerve origin of the masses weren't found but we suggested that the origin could be the peripheral root of the hypoglossal nerve.

The tongue schwannomas can be located at all parts of the tongue but were mostly located at one side of the tongue (36.3\%), following base $(24.2 \%)$, tip (21.2\%) and ventral surface (15.1\%) in our review.

Symptoms of tongue schwannomas include painless swelling and tenderness, snoring, pain, otalgia, dysphagia, and change of the voice quality. At our review, masses at the base of the tongue had snoring, dysphagia, otalgia and pain symptoms but masses which were located at the tip and lateral sides, had mostly painless swelling and discomfort due to teeth contact. Moreover if the schwannomas arises in the posterior two-thirds of the tongue, they are more likely to produce debilitating symptoms.

Choice of diagnosis at most of the cases was excisional biopsy. If the masses are excised totally, there is no need to do fine needle biopsy before surgery but masses which were located at base or sublingual portion are exceptions. In our cases, we didn't perform fine needle biopsy and preferred excisional biopsy because of their location and easy surgical approach. 
Histological diagnosis of schwannoma includes the presence of a capsule, Antoni A or Antoni B stroma, and positive stain with S-100. Antoni A (cellular region) demonstrates compacted spindle cells, of which nuclei occasionally line up in palisades, forming Verocay bodies. Antoni B (edematous region) shows loose spindle cells within myxoid matrix (3). An acid S-100 protein in the supporting cells of the central and peripheral nerve can be demonstrated in schwannoma, particularly in the Antoni A areas. Necrosis, cystic degeneration and focal thrombosis can be seen $(5,8)$.

Schwannomas are almost slow-growing, painless masses and it is diagnosed by histopathological examination or imaging modalities. MRI is superior to CT in several aspects. The MRI image is not degraded by dental amalgam or the beam-hardening artifacts that plague CT scanning of the oral cavity. In addition, MRI allows an accurate measurement of tumor size and precise localization in relation to other structures. In our review we observed that mostly MRI was preferred and advised for the tongue base mass because MRI has a high spatial resolution and it shows structure of mass in detail $(13,14)$. If the surgeon is in doubt then imaging modality of choice for schwannomas of the tongue is MRI. There were no need to evaluate with radiological investigation for the masses which were located at tip and lateral site and total excision is the choice for diagnosis and treatment $(10,15)$. In our cases, total excision was preferred instead of imaging studies.

Schwannomas rarely showed changes of tendency to malignancy (3). Malignity was found in $16 \%$ of all schwannomas (8). 9-14\% of malign schwannomas was presented in head and neck (15). Although malignant transformation of a benign schwannoma of the tongue has been controversial, it remains a concern. In our review we didn't find any malignant change of tongue schwannomas.

The surgery must be performed by general anesthesia for masses which were located at base of tongue. Tracheotomy must be kept in mind especially in big masses which were located at the base of tongue $(13,14)$. Cases which were located at lateral and tip, were operated mostly by local anesthesia and no complications were seen in our review.

Total surgical excision is the choice of treatment. Our cases were excised totally under local anesthesia by intraoral approach. The most common approach was the transoral route. All masses were excised totally regarding our review except in four cases; moreover, $90 \%$ intraoral approach was used. If the mass is located at the base of tongue, inaccessible via mouth, and also size is larger than $30 \mathrm{~mm}$, open techniques such as suprahyoid pharyngotomy $(13,16)$, submandibular technique and mandibulotomy with lip splitting (14) should be preferred to avoid significant morbidity. More recently, the use of $\mathrm{CO} 2$ laser for excision of tongue schwannoma has also been reported (17). The goal of surgical therapy is complete resection.

Recurrence of tongue schwannoma is rare. In our review no any recurrence was noted and the longest follow up time was 16 years.

Benign and malignant lesions can be seen on the tongue. The growth, histopathological examination and clinical appearance must be observed in differential diagnosis. Pain and neurologic deficit supports malignancy $(15,18)$. Fibroma, malign fibrous histocytoma, leiomyoma, lipoma, neuroma and adenoma must be considered in the differential diagnosis of the tongue masses (15). Squamous cell carcinoma and salivary gland tumors must be kept in mind in the case of malignancy. Multiple lesions occur in multiple localized schwannomas, von Recklinghausen's disease and Schwannomatosis which is a non-hereditary disease characterized by multiple subcutaneous and intradermal schwannomas along with variety of intracranial tumors (15).

In conclusion, schwannoma of the tongue is a solid and slow-growing tumor which occurs rarely but must be kept in mind at differential diagnosis of tongue masses. Symptoms mostly include pain and tenderness. Total surgical excision is the treatment of choice and intraoral resection is common approach for treatment. Schwannomas rarely showed changes malignancy.

\section{References}

1. Rosen FS, Pou AM. Obstructive supraglottic schwannoma: A case report and review of the literature. Laryngoscope 2002; 112: 997-1002.

2. Colreavy MP, Lacy PD, Hughes J. Head and neck schwannomas - a 10 year review. J Laryngol Otol 2000; 114: 119-124.

3. Magnusson B. Palisded encapsulated neuroma of the oral mucosa. Oral Surg Oral Med Oral Radiol Endod 1996; 82: 302-304.

4. Wilson JA, McLaren K, McIntyre MA, von Haacke NP. Nerve sheath tumors of the head and neck. Ear Nose Throat J 1988; 67: 103. 
5. Zachariades N. Schwannoma of the oral cavity: Review of the literature and report of a case. J Oral Med 1984; 39: 41-43.

6. Hatziotis JC, Asprides H. Neurilemoma (schwannoma) of the oral cavity. Oral Surg Oral Med Oral Pathol 1967; 24: 510-526.

7. Harman G. Schwannoma of the tip of the tongue in a child. Plast Reconst Surg 2004; 114(6): 1657-1658.

8. Das Gupta TK, Brasfield RD, Strong EW, Hadju SI. Benign solitary schwannomas (neurilemomas). Cancer 1968; 24: 355-356.

9. Lee WS, Lee SN. Neurilemmoma of the tongue. Korean Journal of Dermatology 1998; 26: 94-97.

10. Hwang K, Kim SG, Ahn SI, Lee SI. Neurilemmoma of the tongue. J Craniofac S 2005; 16(5): 859-861.

11. Shore-Freedman E, Abrahams C, Recant W, Schneider AB. Neurilemomas and salivary gland tumors of the head and neck following childhood irradiation. Cancer 1983; 51: 2159.

12. Mevio E, Gorini E. Schwannoma of the tongue: One case report. Rev Laryngol Otol Rhinol 2002; 123: 259261.

13. Ying Y-LM, Zimmer LA, Myers EN. Base of tongue schwannoma: A case report. Laryngoscope 2006; 116: 1284-1287.

14. de Bree R, Westerveld G-J, Smeele LE. Submandibular approach for excision of a large schwannoma in the base of tongue. Eur Arch Otorhinolaryngol 2000; 257: 283-286.

15. Pfeifle R, Baur DA, Paulino A. Schwannoma of the tongue: Report of 2 cases. J Oral Maxillofac Surg 2001; 59: 802.

16. Hsu YC, Hwang CF, Hsu RF, Kuo FY, Chen CY. Schwannoma (neurilemmoma) of the tongue. Acta Otolaryngol 2006; 126: 861-865.

17. Mehrzad H, Persaud R, Papadimitriou N, Kaniyur S, Mochloulis G. Schwannoma of the tongue base treated with transoral carbon dioxide laser. Lasers Med Sci 2006; 21: 235-237.

18. Cincık H, Gungor A, Baloglu H, Colak A, Candan H. Nerve sheath tumours localized on head and neck: Report of three cases. Turkish Archives of Otolaryngology 2004; 42(4): 220-224.

19. Pereira LJ, Pereira PP, dos Santos Jde P. Lingual schwannoma involving the posterior lateral border of the tongue in a young individual: Case report. J Clin Pediatr Dent 2008; 33 (1): 59-62.

20. Patnayak R, Anuradha SV, Uppin SM. Schwannoma of tongue - a case report and short review of literature. Acta Oncol 2007; 46(2): 265-266.

21. Enoz M, Suoglu Y, Ilhan R. Lingual schwannoma. J Cancer Res Ther. 2006; 2(2): 76-78.

22. Sardinha S, Paza A. Schwannoma of the oral cavity. Histological and immunohistochemical features. Brazilian Journal of Oral Sciences 2005; 14: 806-809.
23. Nakasato T, Kamada Y, Ehara S. Multilobular neurilemmoma of the tongue in a child. AJNR Am J Neuroradiol. 2005; 26 (2): 421-423.

24. Jornet P, Fenoll A. Neurilemmoma of the tongue. Oral oncology 2005; 41,154-157.

25. Vafiadis M, Fiska A, Panopoulou M, Assimakopoulos D. A clinical case report of a Schwannoma on the tip of the tongue. B-ENT 2005; 1: 201-204.

26. Bassichis BA, McClay JE. Pedunculated neurilemmoma of the tongue base. Otolaryngol Head Neck Surg 2004; 130: 639-641.

27. Tamaki J, Uchiyama Y, Ozona K. A case of schwannoma in the tongue diagnosed with enhanced magnetic resonance image. Oral Radiology 2004; 20: 83-86.

28. Kumar A, Rajan P, Trainee P. Schwannoma of the tongue -case report. Calicut Medical Journal 2004; 2 (2): 4 .

29. Arda HN, Akdogan O, Arda N. An unusual site for an intraoral schwannoma: A case report. Am J Otolaryngol 2003; 24(5): 348-350.

30. Go JH. Benign peripheral nerve sheath tumor of the tongue. Yonsei Med J 2002; 43(5): 678-680.

31. Spandow O, Fagerlund M, Bergmark L, Boquist L. Clinical and histopathological features of a large parapharyngeal neurilemmoma located at the base of tongue. ORL 1999; 61: 25-30.

32. Nelson W, Chuprevich T, Galbraith DA. Enlarging tongue mass. J Oral Maxillofac Surg 1998; 56(2): 224227.

33. Nakayama H, Gobara R, Shimamoto F, Kajihara H. Ancient schwannoma of the oral Xoor and ventricular portion of the tongue: a case report and review of the literature. Jpn J Clin Oncol 1996; 26: 185-188

34. Karaca CT, Habesoglu TE, Naiboglu B. Schwannoma of the tongue in A child. Am J Otolaryngol 2010; 31(1): 46-48.

35. Lukšić I, Müller D, Virag M. Schwannoma of the tongue in a child. J Craniomaxillofac Surg 2010; Oct 30:

36. Jeffcoat BT, Pitman KT, Brown AS. Schwannoma of the oral tongue. Laryngoscope. 2010; 120 Suppl 4: S154.

37. Santos PP, Freitas VS, Pinto LP. Clinicopathologic analysis of 7 cases of oral schwannoma and review of the literature. Ann Diagn Pathol 2010; 14(4): 235-239.

38. Naidu GS, Sinha SM. Schwannoma of the tongue: An unusual presentation in a child. Indian J Dent Res 2010; 21(3): 457-459.

39. Gupta P, Garg A, Dhingra KK. Schwannoma tongue: Arare entity. ANZ J Surg 2009; 79(1-2): 93-94.

40. Cohen M, Wang MB. Schwannoma of the tongue: Two case reports and review of the literature. Eur Arch Otorhinolaryngol. 2009; 266(11): 1823-1829.

41. Sawhney R, Carron MA, Mathog RH. Tongue base schwannoma: Report, review, and unique surgical approach. Am J Otolaryngol 2008; 29(2): 119-22. 